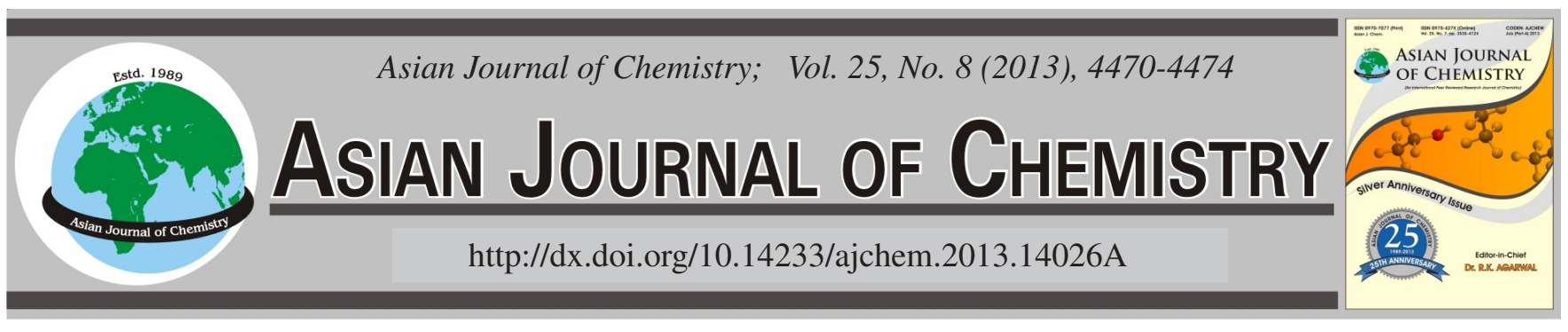

\title{
Synthesis and Study of Physico-Chemical Behaviour of Complexes Containing Heterometallic Trinuclear Triangular Metal-Sulfur-Cubiodal $\left\{\mathrm{WMo}_{2} \mathrm{~S}_{4}\right\}^{4+}$ Core
}

\author{
RAMJEE SAH* and BALRAMJEE SAH
}

University Department of Chemistry, B.R.A. Bihar University, Muzaffarpur-842 001, India

*Corresponding author: E-mail: ramjeebrabu@yahoo.co.in

\begin{abstract}
Chromatographic separation of mixture leads to the isolation of molybdenum-tungsten mixed-metal clusters $\left[\mathrm{MoW}_{2} \mathrm{~S}_{4}\left(\mathrm{H}_{2} \mathrm{O}\right)_{9}\right]^{4+}$ and $\left[\mathrm{WMo}_{2} \mathrm{~S}_{4}\left(\mathrm{H}_{2} \mathrm{O}\right)_{9}\right]^{4+}$. From the aqua ion the corresponding oxalato-derivatives as $\left[\mathrm{MoW}_{2} \mathrm{~S}_{4}\left(\mathrm{C}_{2} \mathrm{O}_{4}\right)_{3}\left(\mathrm{H}_{2} \mathrm{O}\right)_{3}\right]^{2-}$ and $\left[\mathrm{WMO}_{2} \mathrm{~S}_{4}\left(\mathrm{C}_{2} \mathrm{O}_{4}\right)_{3}\left(\mathrm{H}_{2} \mathrm{O}\right)_{3}\right]^{2-}$ were isolated. The peak positions of the two big bands in each infrared spectrum of the four aqua clusters, $\left[\mathrm{Mo}_{3} \mathrm{~S}_{4}\left(\mathrm{H}_{2} \mathrm{O}\right)_{9}\right]^{4+},\left[\mathrm{W}_{3} \mathrm{~S}_{4}\left(\mathrm{H}_{2} \mathrm{O}\right)_{9}\right]^{4+}$, $\left[\mathrm{MoW}_{2} \mathrm{~S}_{4}\left(\mathrm{H}_{2} \mathrm{O}\right)_{9}\right]^{4+}$ and $\left[\mathrm{WMo}_{2} \mathrm{~S}_{4}\left(\mathrm{H}_{2} \mathrm{O}\right)_{9}\right]^{4+}$ in the $550-400 \mathrm{~cm}^{-1}$ region shift to lower wave number when the molybdenum atom is replaced by tungsten. The cyclic voltammogramms of $\mathrm{Cs}_{2}\left[\mathrm{MoW}_{2} \mathrm{~S}_{4}\left(\mathrm{C}_{2} \mathrm{O}_{4}\right)_{3}\left(\mathrm{H}_{2} \mathrm{O}\right)_{3}\right](\mathbf{1}) \mathbf{B}$ and $\mathrm{Cs}_{2}\left[\mathrm{WMo}_{2} \mathrm{~S}_{4}\left(\mathrm{C}_{2} \mathrm{O}_{4}\right)_{3}\left(\mathrm{H}_{2} \mathrm{O}\right)_{3}\right](2)$ shows three consecutive one-electron reduction steps in the aqueous medium with supporting electrolyte, $\mathrm{KCl}$ at $-0.84,-1.40,-1.78$ and $-0.73,-1.22,-1.66 \mathrm{~V}$ respectively. These steps correspond to the change of oxidation states of three metals in each cluster with the following electronic configuration $\left\{\mathrm{M}_{3}\right\}^{6} \rightarrow\left\{\mathrm{M}_{3}\right\}^{7} \rightarrow\left\{\mathrm{M}_{3}\right\}^{8} \rightarrow\left\{\mathrm{M}_{3}\right\}^{9}$. The half wave potential $\mathrm{E}_{1 / 2}$ are significantly dependent on the cluster metals. In all the reduction processes the $\left[\mathrm{Mo}_{\mathrm{n}} \mathrm{W}_{3-\mathrm{n}} \mathrm{S}_{4}\left(\mathrm{C}_{2} \mathrm{O}_{4}\right)_{3}\left(\mathrm{H}_{2} \mathrm{O}\right)_{3}\right]^{2-}$ clusters $(\mathrm{n}=0-3)$ are easily reduced with the increase in the number of Mo(n) in the clusters. The proceeding reduction centre of the molybdenum-tungsten mixed metal clusters is mainly on the Mo atom(s) rather than $\mathrm{W}$ atoms.
\end{abstract}

Key Words: Electrochemistry, Sulfur-bridged, Incomplete cubanes-type, Heterometallic cuboidal, Core.

\section{INTRODUCTION}

The structure and function of the various molybdoenzyme continues to much attention. Recent years have seen a dramatic expansion in the synthetic and structural molybdenum-sulfur as well as tungsten-sulfur chemistry. It is well known that molybdenum has an extraordinary proclivity to form binuclear and cluster compounds containing terminal $\mu_{2-}$ or $\mu_{3-}$ sulfur atoms, some of which are of biological importance ${ }^{1}$. Multinuclear transition metal-sulfur complexes are of well-established significance in bio-chemistry, while extended-lattice transition metal-sulfur solids i.e. $\mathrm{MoS}_{2}$ are ubiquitous in industrial hydro treating catalysis. Many reports have been made on the trinuclear triangular tungsten and also molybdenum compounds in which metal atoms are bridged by several kinds of atoms or ligands like $\mu_{2-} \mathrm{O}, \mu_{2-} \mathrm{S}, \mu_{3-} \mathrm{S}, \mu_{3-} \mathrm{NH}$ and $\mu_{3-} \mathrm{Cl}^{2,3}$. Molybdenum and tungsten sulfur compounds have attracted much attention and a large number of sulfur-bridged molybdenum and tungsten compounds have appeared.

It has recently been reported that the reaction of the incomplete cubane-type $\mathrm{Mo}_{3} \mathrm{~S}_{4}{ }^{4+}$ aqua ion with metallic iron, cobalt or nickel gives the corresponding heterometallic cubanetype $\left[\mathrm{M}^{\prime} \mathrm{Mo}_{3} \mathrm{~S}_{4}\right] 4^{+}$aqua ion where $\mathrm{M}^{\prime}=\mathrm{Fe}, \mathrm{Co}, \mathrm{Ni}$, however, the number of triangular trinuclear heterometallic molybdenum-tungsten mixed metal compounds are limited ${ }^{4-7}$. $\left[\mathrm{Mo}_{2} \mathrm{WS}_{4}\left(\mathrm{C}_{5}\left(\mathrm{CH}_{5}\right)_{3}\right]\right.$ reputed by Wachter and co-workers ${ }^{8}$, is the only cluster to have the molybdenum-tungsten mixedmetal core, though some-metal clusters with incomplete cubane-type $\mathrm{M}_{2} \mathrm{M}^{\prime} \mathrm{S}_{4}$ cores $\left(\mathrm{M}=\mathrm{Mo}\right.$ or $\mathrm{W} ; \mathrm{M}^{\prime}=$ other metal) have been reported ${ }^{9,10}$.

The authors report the synthesis and electrochemical benhaviour of incomplete cubane-type molybdenum(IV)tungsten(IV) mixed-metal aqua cluster compounds and their corresponding oxalato derivatives, i.e. $\mathrm{Cs}_{2}\left[\mathrm{MoW}_{2} \mathrm{~S}_{4}\left(\mathrm{C}_{2} \mathrm{O}_{4}\right)_{3}\right.$ $\left.\left(\mathrm{H}_{2} \mathrm{O}\right)_{3}\right]$ and $\mathrm{Cs}_{2}\left[\mathrm{WMo}_{2} \mathrm{~S}_{4}\left(\mathrm{C}_{2} \mathrm{O}_{4}\right)_{3}\left(\mathrm{H}_{2} \mathrm{O}\right)_{3}\right]$.

Investigation have been made to find out the interaction between molybdenum and tungsten and also to compare the character of the elements in the incomplete cubane-type clusters with $\left[\mathrm{WnMo}_{3-\mathrm{n}} \mathrm{S}_{4}\right]^{4+}$ cores $(\mathrm{n}=0-3)$.

\section{EXPERIMENTAL}

IR spectra of these complexes recorded on Perkin-Elmer model 580 infrared spectrophotometer. The samples were prepared as CsI pellets and referenced to polystyrene bands. The electronic spectra of the complexes were recorded on 
Shimadzu. UV-VIS 190 and Perkin-Elmer $\lambda_{2}$ double beam spectrophotometers using matched quartz cell.

The cyclic voltammograms were recorded on a bioanalytical system CV-27 voltammogramm, in the connection with a C1B-cell stand. All the experiments were performed in a standard three electrode configuration using an auxiliary Ptelectrode, a glassy carbon working electrode and a saturated calomel electrode under dry nitrogen atmosphere. All the results were collected at $298 \mathrm{~K}$ and referenced to saturated calomel electrode (SCE) was used as supporting electrolyte for aqueous medium. The reported values were uncorrected for junction potential where voltammograms were recorded in different scan speeds but with the scan speed at $100 \mathrm{mV} / \mathrm{s}$ was used for discussion.

All the reagents and solvents were of A.R. grade and were used without further purification. Water was distilled in quickfit apparatus over allkaline $\mathrm{KMnO}_{4}$ and $\mathrm{H}_{2} \mathrm{SO}_{4}$. The electric conductance of distilled water varied between $7 \times 10^{-7}$ to $9 \times$ $10^{-9} \Omega^{-1} \mathrm{~cm}^{-1}$. Elemental analyses were performed by EA-1108 elemental analyzer. Sulfur and molybdenum were analyzed by the oxidizing the compound by peroxide fusion as $\mathrm{BaSO}_{4}$ and molybdenum oxinate respectively. $p$-Toluenesulfonic acid (HPTS) was used after recrystallization. Sodium borohydride, oxalic acid, $\mathrm{CsCl}$ as well as most other reagents were commercial grade and were used as received. $\left(\mathrm{NH}_{4}\right)_{2} \mathrm{MoS}_{4}$ and $\left(\mathrm{NH}_{4}\right)_{2} \mathrm{WS}_{4}$ were synthesized by published procedure.

\section{Synthesis of compounds}

$\mathbf{C s}_{2}\left[\mathbf{M o W}_{2} \mathbf{S}_{4}\left(\mathbf{C}_{2} \mathbf{O}_{4}\right)_{3}\left(\mathbf{H}_{2} \mathbf{O}\right)_{3}\right] \cdot \mathbf{2} \mathbf{H}_{2} \mathbf{O}(\mathbf{1}):\left(\mathrm{NH}_{4}\right)_{2} \mathrm{WS}_{4}(3.48$ gm, $10 \mathrm{~m} \mathrm{~mol}\}$ was dissolved in water $(200 \mathrm{~mL})$. $\left(\mathrm{NH}_{4}\right)_{2} \mathrm{~S}_{2} \mathrm{O}_{8}$ $(1.14$ g. $5 \mathrm{~m} \mathrm{~mol})$ was added to the solution and the reaction mixture was allowed to stir constantly for $1 \mathrm{~h}$ at room temperatures. A prepared solution dissolving $\left(\mathrm{NH}_{4}\right)_{2} \mathrm{MoS}_{4}(1.3 \mathrm{~g}$, $5 \mathrm{mmol})$ in water $(50 \mathrm{~mL})$ was mixed to the constantly stirred reaction mixture of $\left(\mathrm{NH}_{4}\right)_{2} \mathrm{WS}_{4}$. The entire reaction mixture was allowed to reduce heterogeneously by adding $\mathrm{NaBH}_{4}(5 \mathrm{~g}$, $0.125 \mathrm{~mol}$ ) portion wise (ca $0.5 \mathrm{~g}$ at each interval) and $50 \mathrm{~mL}$ of $6 \mathrm{M} \mathrm{HCl}$ acid (using $5 \mathrm{~mL}$ at each interval) alternatively. The reduction of reaction mixture was continued for $2 \mathrm{~h}$. After the consumption of reducing agent an additional amount 250 $\mathrm{mL}$ of $2 \mathrm{M} \mathrm{HCl}$ acid was added to the solution, which was heated at $90{ }^{\circ} \mathrm{C}$ for $6 \mathrm{~h}$ with constant introduction of an air stream. During the course of heating $1 \mathrm{M} \mathrm{HCl}$ was added occasionally to keep the volume of the solution constant ( $c a$. $300 \mathrm{~mL}$ ). The solution was allowed to cool at room temperature and filtered under section.

The filtrate was subjected for chromatographic separation using Sephadex G-15 column $(4.0 \mathrm{~cm} \times 100 \mathrm{~cm}, 1 \mathrm{M} \mathrm{HCl})$. The gray coloured bands were collected and concentrated by the use of a cation exchange, Dowex $50 \mathrm{~W}-\mathrm{X}_{8}(2 \mathrm{MHCl})$. Sephadex G-15 column chromatography $(2.0 \mathrm{~cm} \times 150 \mathrm{~cm}$, $1 \mathrm{M} \mathrm{HCl}$ ) was applied again for purification. This purification for concentration process was repeated again. The dark grey band appeared at the top of column was eluted finally by using oxalic acid solution (350 mg in $20 \mathrm{~mL}$ water). To this elute, cesium chloride $(168 \mathrm{~mL}, 1 \mathrm{mmol})$ was added and then the resultant solution was allowed to evaporate under conc. $\mathrm{H}_{2} \mathrm{SO}_{4}$ acid desiccators. The initial white precipitate was filtered and from the mother liquour dark black plate shaped crystals were separated out, that was filtered, washed with minimum amount of cold water, then with methanol and finally with ether and then dried under vacuum to yield with $75 \%$ of the product based on the starting material.

Anal: found (calcd.) $\%$ for $\mathrm{C}_{6} \mathrm{H}_{10} \mathrm{O}_{17} \mathrm{~S}_{4} \mathrm{MoW}_{2} \mathrm{Cs}_{2}$ ): C: 6.02 (5.94); H: 0.84 (0.8250), O: 9.57 (9.24); S: 10.12 (10.56), Mo: 7.80 (7.92); W: $30.40(30.36)$.

$\left.\mathrm{Cs}_{2}\left[\mathrm{WMo}_{2} \mathrm{~S}_{4}\left(\mathrm{C}_{2} \mathrm{O}_{4}\right)_{3} \mathrm{H}_{2} \mathrm{O}\right)_{3}\right] \cdot \mathbf{2} \mathbf{H}_{2} \mathrm{O}$ (2): The entire synthetic procedure was followed exactly similar to that used for the preparation of (1) was employed using $\left(\mathrm{NH}_{4}\right)_{2} \mathrm{MoS}_{4}(2.6 \mathrm{~g} 10$ $\mathrm{mmol})$ and $\left(\mathrm{NH}_{4}\right)_{2} \mathrm{WS}_{4}(1.74 \mathrm{gn}, 5 \mathrm{mmol})$ instead of using the ratio of Mo:W as 1:2. The final product was isolated as dark green needle shaped crystal with $70 \%$ yield based on the starting material.

Anal: Found (calcd.) $\%$ for $\left.\mathrm{C}_{6} \mathrm{H}_{10} \mathrm{O}_{17} \mathrm{~S}_{4} \mathrm{Mo}_{2} \mathrm{WCs}_{2}\right)$ : C:6.56 (6.40); H: 0.92 (0.89); O: 10.08 (9.96) S: 11.68 (11.38); W: 16.42 (16.37); Mo: 17.34 (17.08).

\section{RESULTS AND DISCUSSION}

Synthesis and properties of molybdenum (IV)-tungsten (IV) mixed-metal clusters with $\left\{\mathrm{MoW}_{2} \mathrm{~S}_{4}\right\}^{4+}$ and $\left\{\mathrm{WMo}_{2} \mathrm{~S}_{4}\right\}^{4+}$ cores: Two types of reaction for the synthesis of the mixed metal clusters have been tried during the study.

Type-1, reduction of a mixture of $\mathrm{Mo}(\mathrm{VI})$ and $\mathrm{W}(\mathrm{V})$ or a mixture of $\mathrm{W}(\mathrm{VI})$ and $\mathrm{Mo}(\mathrm{V})$ by $\mathrm{NaBH}_{4}$ in acidic medium.

Type-2, the reduction of a mixture of Mo(VI) and W(V) or $\mathrm{W}(\mathrm{VI})$ and $\mathrm{Mo}(\mathrm{V})$ by $\mathrm{Mo}(\mathrm{III})$ or W(III) compounds. The method described in the experimental section employs a reaction of type 1 as described in Scheme-I.

A.

$\begin{aligned} 2\left(\mathrm{NH}_{4}\right)_{2} \mathrm{MoS}_{4}+2 \mathrm{H}_{2} \mathrm{O}+\left(\mathrm{NH}_{4}\right)_{2} \mathrm{~S}_{2} \mathrm{O}_{8} \rightarrow & \left(\mathrm{NH}_{4}\right)_{2}\left[\mathrm{Mo}_{2} \mathrm{O}_{2} \mathrm{~S}_{2}\left(\mathrm{~S}_{2}\right)_{2}\right] \\ + & +2\left(\mathrm{NH}_{4}\right)_{2} \mathrm{SO}_{4}+2 \mathrm{H}_{2} \mathrm{~S} \\ \left(\mathrm{NH}_{4}\right)_{2} \mathrm{WS} 4+\left(\mathrm{NH}_{4}\right)_{2}\left[\mathrm{Mo}_{2} \mathrm{O}_{2} \mathrm{~S}_{2}\left(\mathrm{~S}_{2}\right)_{2}\right]+ & \mathrm{NaBH} \mathrm{HaH}_{4}+\mathrm{HCl} \rightarrow\left[\mathrm{WMO}_{2}\right.\end{aligned}$ $\left.\mathrm{S}_{4}\left(\mathrm{H}_{2} \mathrm{O}\right)_{9}\right] \mathrm{Cl}_{4}+\ldots$

B. $\begin{aligned} 2\left(\mathrm{NH}_{4}\right)_{2} \mathrm{WS}_{4}+2 \mathrm{H}_{2} \mathrm{O}+\left(\mathrm{NH}_{4}\right)_{2} \mathrm{~S}_{2} \mathrm{O}_{8} \rightarrow & \left(\mathrm{NH}_{4}\right)_{2}\left[\mathrm{~W}_{2} \mathrm{O}_{2} \mathrm{~S}_{2}\left(\mathrm{~S}_{2}\right)_{2}\right]+ \\ & 2\left(\mathrm{NH}_{4}\right)_{2} \mathrm{SO}_{4}+2 \mathrm{H}_{2} \mathrm{~S}\end{aligned}$

$\left(\mathrm{NH}_{4}\right)_{2} \mathrm{MoS}_{4}+\left(\mathrm{NH}_{4}\right)_{2}\left[\mathrm{~W}_{2} \mathrm{O}_{2} \mathrm{~S}_{2}\left(\mathrm{~S}_{2}\right)_{2}\right]+\mathrm{NaBH}_{4}+\mathrm{HCl} \rightarrow\left[\mathrm{MoW}_{2}\right.$ $\left.\mathrm{S}_{4}\left(\mathrm{H}_{2} \mathrm{O}\right)_{9}\right] \mathrm{Cl}_{4}+\ldots$

The combination of the starting materials gave better yields of $\left[\mathrm{MoW}_{2} \mathrm{~S}_{4}\left(\mathrm{H}_{2} \mathrm{O}\right)_{9}\right]^{4+}$ and $\left[\mathrm{WMo}_{2} \mathrm{~S}_{4}\left(\mathrm{H}_{2} \mathrm{O}\right)_{9}\right]^{4+}$ than any other methods. The oxidation states of molybdenum and tungsten in the mixed-metal clusters are four. The mixed-metal clusters are stable towards air-oxidation and the absorption spectra of the clusters in $2 \mathrm{M} \mathrm{HCl}$ or in the freshly prepared 2MHPTS solutions do not change for several days in the air. The use of $\left(\mathrm{NH}_{4}\right)_{2} \mathrm{~S}_{2} \mathrm{O}_{8}$ as an external oxidant for $\left(\mathrm{NH}_{4}\right)_{2} \mathrm{WS}_{4}$ or $\left(\mathrm{NH}_{4}\right) \mathrm{MoS}_{4}$ leads to the quantitative generation of mixedmetal trimer core. It has been observed that a solution containing the mixture of $\left(\mathrm{NH}_{4}\right)_{2} \mathrm{WS}_{4}$ and $\left(\mathrm{NH}_{4}\right)_{2} \mathrm{MoS}_{4}$ the either in the stoichiometric ratio of $2: 1,1: 2$ or $1: 1$ without use of $\left(\mathrm{NH}_{4}\right)_{2} \mathrm{~S}_{2} \mathrm{O}_{8}$ when subject for reaction under the similar condition produced a gray-coloured solution which on chromatographic separation resulted a separation of two distnict bands, blue-violet band at top $\left(\lambda_{\max }=570 \mathrm{~nm}\right)$ and green band at bottom $\left(\lambda_{\max }=609 \mathrm{~nm}\right)$ responsible for $\left[\mathrm{W}_{3} \mathrm{~S}_{4}\left(\mathrm{H}_{2} \mathrm{O}\right)_{9}\right]^{4+}$ and $\left[\mathrm{Mo}_{3} \mathrm{~S}_{4}\left(\mathrm{H}_{2} \mathrm{O}\right)_{9}\right]^{4+}$ respectively. The suggests about the crucial role of pentavalent thio-metallate $(\mathrm{V})$ in the generation of mixed-metal trimeric core. 
TABLE-1

ELECTRONIC SPECTRAL DATA FOR TRIMER WITH $\left\{\mathrm{WnMo}_{3}-\mathrm{nS}_{4}\right\}^{4+}$ CORES

\begin{tabular}{clll}
\hline No. & Compound & $\lambda_{\max } \mathrm{nm}\left(\mathrm{M}^{-1}, \mathrm{~m}^{-1}\right)$ & Ref. \\
\hline 1 & {$\left[\mathrm{Mo}_{3} \mathrm{~S}_{4}\left(\mathrm{H}_{2} \mathrm{O}\right)_{9}\right](\mathrm{PTS})_{4}$} & $602(351), 367(5190)$ & This work \\
2 & {$\left[\mathrm{~W}_{3} \mathrm{~S}_{4}\left(\mathrm{H}_{2} \mathrm{O}\right)_{9}\right](\mathrm{PTS})_{4}$} & $560(490)] 430 \mathrm{sh}(330), 314(7040)$ & This work \\
3 & {$\left[\mathrm{MoW}_{2} \mathrm{~S}_{4}\left(\mathrm{H}_{2} \mathrm{O}\right)_{9}\right](\mathrm{PTS})_{4}$} & $572(380), 500(340) 400 \operatorname{sh}(1400), 340(6500)$ & This work \\
4 & {$\left[\mathrm{WMo}_{2} \mathrm{~S}_{4}\left(\mathrm{H}_{2} \mathrm{O}\right)_{9}\right](\mathrm{PTS})_{4}$} & $600(340), 500 \mathrm{Sh}(300) 440 \operatorname{sh}(920), 350(4900)$ & This work \\
5 & $\mathrm{Cs}_{2}\left[\mathrm{Mo}_{3} \mathrm{~S}_{4}\left(\mathrm{C}_{2} \mathrm{O}_{4}\right)_{3}\left(\mathrm{H}_{2} \mathrm{O}\right)_{3}\right] \cdot 2 \mathrm{H}_{2} \mathrm{O}$ & $622(252), 366(3623) 256(9210)$ & To be published \\
6 & $\mathrm{Cs}_{2}\left(\mathrm{~W}_{3} \mathrm{~S}_{4}\left(\mathrm{C}_{2} \mathrm{O}_{4}\right)_{3}\left(\mathrm{H}_{2} \mathrm{O}\right)_{3}\right] \cdot 2 \mathrm{H}_{2} \mathrm{O}$ & $586(572), 361(1556) 305(8265), 253(12470)$ & To be published \\
7 & $\mathrm{Cs}_{2}\left[\mathrm{MoW}_{2} \mathrm{~S}_{4}\left(\mathrm{C}_{2} \mathrm{O}_{4}\right)_{3}\left(\mathrm{H}_{2} \mathrm{O}\right)\right] \cdot 2 \mathrm{H}_{2} \mathrm{O}$ & $590(480), 515(425400 \mathrm{Sh}(1630), 340(6000), 235 \mathrm{sh}(24000)$ & This work \\
8 & $\mathrm{Cs}_{2}\left[\mathrm{WMO}_{2} \mathrm{~S}_{4}\left(\mathrm{C}_{2} \mathrm{O}_{4}\right)_{3}\left(\mathrm{H}_{2} \mathrm{O}\right)_{3}\right] \cdot 2 \mathrm{H}_{2} \mathrm{O}$ & $620(430), 500 \mathrm{Sh}(410) 425 \operatorname{sh}(1500), 360(5200) 245 \mathrm{sh}(19200)$ & This work \\
\hline
\end{tabular}

The resultant oxalato complexes were analyzed to give $\mathrm{S} / \mathrm{W}=2.02 \pm 0.05$ and $3.98 \pm 0.05$ (four determination) for $\left\{\mathrm{MoW}_{2} \mathrm{~S}_{4}\right\}^{4+}$ and $\left\{\mathrm{WMo}_{2} \mathrm{~S}_{4}\right\}^{4+}$ core respectively. Sulfur was determined gravimetrically as $\mathrm{BaSO}_{4}$ and tungsten by the thiocyanate photometric method). The change of the ion was estimated to be $4+$ on the basis of its behaviour similar to that of the $\mathrm{Mo}_{3} \mathrm{~S}_{4}{ }^{4+}$ or $\mathrm{W}_{3} \mathrm{~S}_{4}{ }^{4+}$ aqua ion on the ion exchanger.

The proposed structure for both derivatives has schematically been represented in the following Fig. 1.

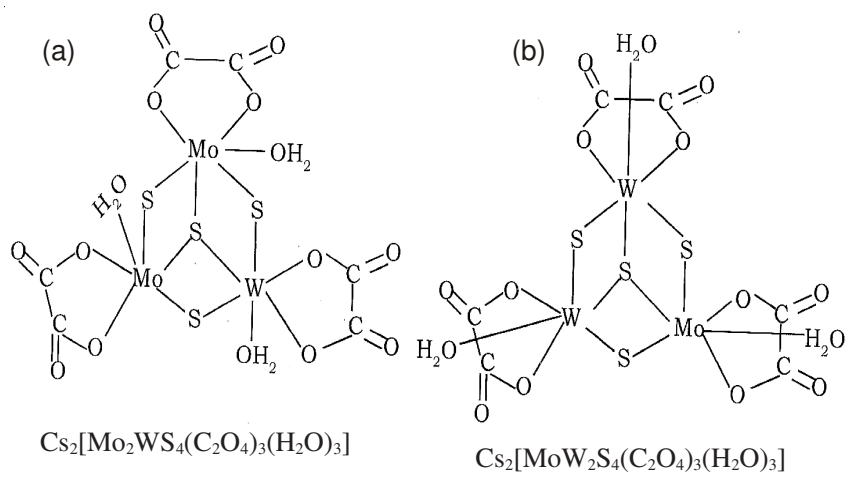

Fig.1.

Electronic spectral study: Electronic spectra of $\left[\mathrm{MoW}_{2} \mathrm{~S}_{4}\left(\mathrm{H}_{2} \mathrm{O}\right)_{9}\right]^{4+}$ and $\left[\mathrm{WMo}_{2} \mathrm{~S}_{4}\left(\mathrm{H}_{2} \mathrm{O}\right)_{9}\right]^{4+}$ along with their corresponding oxalato derivatives have been depicted in the Figs. 2 and 3 respectively in the UV-visible region.

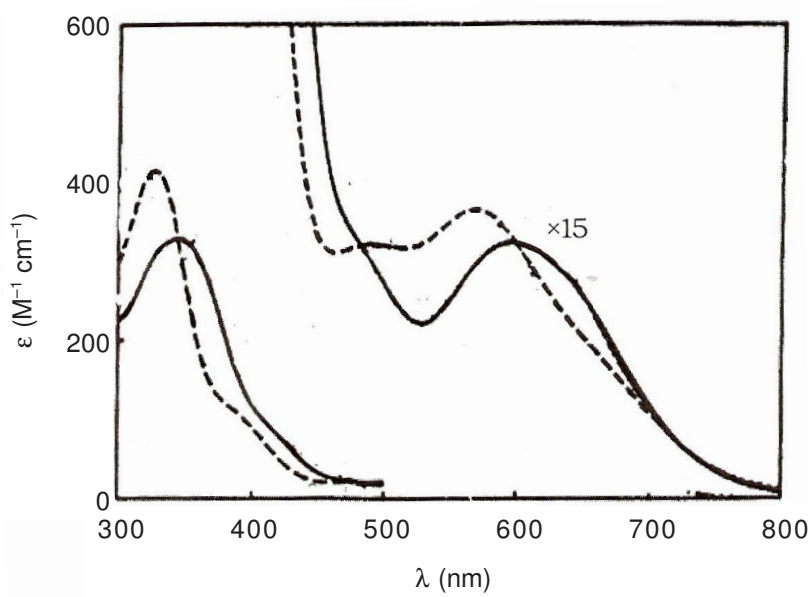

Fig. 2. Electronic spectra of $\left[\mathrm{Mo}_{3-\mathrm{n}} \mathrm{W}_{\mathrm{n}} \mathrm{S}_{4}\left(\mathrm{H}_{2} \mathrm{O}\right)_{2}\right]^{4+}$ clusters $(\mathrm{n}=1-2)$ in $2 \mathrm{M}$ HPTS: (-) $\left.\mathrm{Mo}_{2} \mathrm{WS}_{4}\left(\mathrm{H}_{2} \mathrm{O}\right)_{9}\right]^{4+}$ and (- -) $\left[\mathrm{MoW}_{2} \mathrm{~S}_{4}\left(\mathrm{H}_{2} \mathrm{O}\right)_{9}\right]^{4+}$

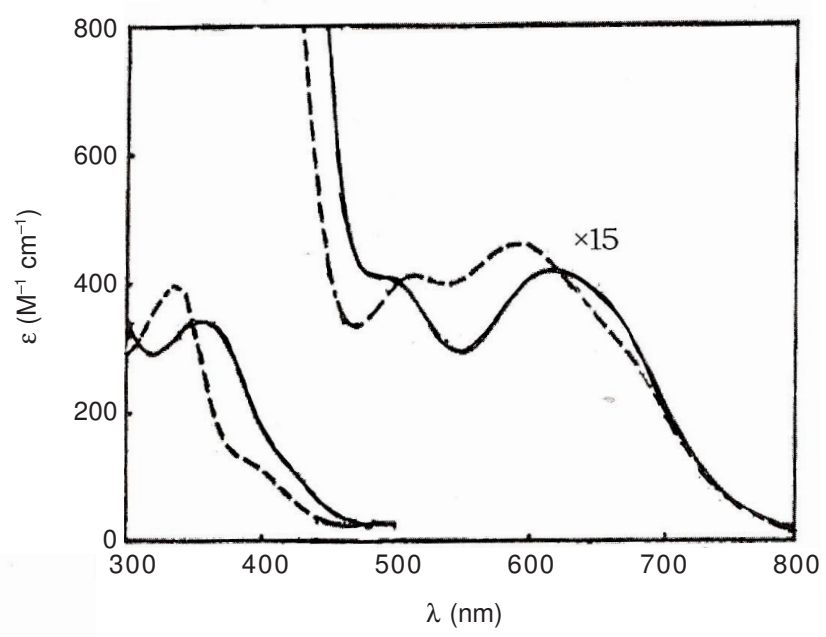

Fig. 3. Electronic spectra of $\left[\mathrm{Mo}_{3-n} \mathrm{~W}_{\mathrm{n}} \mathrm{S}_{4}\left(\mathrm{C}_{2} \mathrm{O}_{4}\right)_{3}\left(\mathrm{H}_{2} \mathrm{O}\right)_{3}\right]^{2-}$ clusters $(\mathrm{n}=1-2)$ in $0.2 \mathrm{M} \mathrm{KCl}$ : (-) $\left.\mathrm{Mo}_{2} \mathrm{WS}_{4}\left(\mathrm{C}_{2} \mathrm{O}_{4}\right)_{3}\left(\mathrm{H}_{2} \mathrm{O}\right)_{3}\right]^{2-}$ and (- -) $\left[\mathrm{MoW}_{2} \mathrm{~S}_{4}\right.$ $\left.\left(\mathrm{C}_{2} \mathrm{O}_{4}\right)_{3}\left(\mathrm{H}_{2} \mathrm{O}\right)_{3}\right]^{2-}$

The peak positions (nm) and $\varepsilon$-value are given in Table1. A distinct splittings of absorption peaks in the visible regions are observed in the mixed metal aqua ions and the corres pending oxalato derivatives. The longer peak wavelength positions for the four aqua ions and of the four oxalatoderivatives shift to the longer wave length, respectively, when the tungsten atom is replaced by molybdenum.

It was demonstrated by the following two experiments that the clusters $\left[\mathrm{MoW}_{2} \mathrm{~S}_{4}\left(\mathrm{H}_{2} \mathrm{O}\right)_{9}\right]^{4+}$ and $\left[\mathrm{WMo}_{2} \mathrm{~S}_{4}\left(\mathrm{H}_{2} \mathrm{O}\right)_{9}\right]^{4+}$ are not a mixture of $\left[\mathrm{Mo}_{3} \mathrm{~S}_{4}\left(\mathrm{H}_{2} \mathrm{O}\right)_{9}\right]^{4+}$; as: (1) The mixture of $\left[\mathrm{Mo}_{3} \mathrm{~S}_{4}\left(\mathrm{H}_{2} \mathrm{O}\right)_{9}\right]^{4+}$ and $\left[\mathrm{W}_{3} \mathrm{~S}_{4}\left(\mathrm{H}_{2} \mathrm{O}\right)_{9}\right]^{4+}$ is clearly separated into two bands by Sephadex G-15 column chromatography, where as the $\left[\mathrm{MoW}_{2} \mathrm{~S}_{4}\left(\mathrm{H}_{2} \mathrm{O}\right)_{9}\right]^{4+}$ or $\left[\mathrm{WMo}_{2} \mathrm{~S}_{4}\left(\mathrm{H}_{2} \mathrm{O}\right)_{9}\right]^{4+}$ cluster is not separated by the method and (2) the electronic spectrum of the $\left[\mathrm{MoW}_{2} \mathrm{~S}_{4}\left(\mathrm{H}_{2} \mathrm{O}\right)_{9}\right]^{4+}$ cluster is clearly different from that of the mixture of $\left.33 \% \mathrm{Mo}_{3} \mathrm{~S}_{4}\left(\mathrm{H}_{2} \mathrm{O}\right)_{9}\right]^{4+}$ and $66 \%\left[\mathrm{~W}_{3} \mathrm{~S}_{4}\left(\mathrm{H}_{2} \mathrm{O}\right)_{9}\right]^{4+}$ clusters. The same is true for the $\left[\mathrm{WMo}_{2} \mathrm{~S}_{4}\left(\mathrm{H}_{2} \mathrm{O}\right)_{9}\right]^{4+}$ cluster. Elemental analyses for both Complexes also support the formula as proposed. The proposed structure for both derivatives has schema*tically been represented in Fig. 1.

Infrared spectral study: Muller and co-workers ${ }^{11}$ have extensively studied on molybdenum-sulfur compounds and assigned the band at $460 \mathrm{~cm}^{-1}$ for $\mathrm{v}\left(\mathrm{Mo}_{3}-\mathrm{S}\right)$ vibration in $\left(\mathrm{NH}_{4}\right)_{2}\left[\mathrm{Mo}_{3}\left(\mu_{3}-\mathrm{S}\right)\left(\mu_{2}-\mathrm{S}_{2}\right)_{3}\left(\mathrm{~S}_{2}\right)_{3}\right]$. Infrared spectra of the four aqua clusters, $\left.\left[\mathrm{Mo}_{3} \mathrm{~S}_{4}\left(\mathrm{H}_{2} \mathrm{O}\right)_{9}\right](\mathrm{PTS})_{4},\left[\mathrm{~W}_{3} \mathrm{~S}_{4}\left(\mathrm{H}_{2} \mathrm{O}\right)_{9}\right](\mathrm{PTS})_{4}\right]$, $\left[\mathrm{MoW}_{2} \mathrm{~S}_{4}\left(\mathrm{H}_{2} \mathrm{O}\right)_{9}\right](\mathrm{PTS})_{4}$ and $\left[\mathrm{WMo}_{2} \mathrm{~S}_{4}\left(\mathrm{H}_{2} \mathrm{O}\right)_{9}\right](\mathrm{PTS})_{4}$ shows $v\left(\mathrm{M}_{3}-\mathrm{S}\right)$ vibration in the region of $550-400 \mathrm{~cm}^{-1}$. Each spectrum was two large absorption bands in the region. The peak 
position shift to the lower wave number when the molybdenum atom is replaced by the tungsten atom. The bands are tentatively assigned to $v\left(\mathrm{M}-\mathrm{OH}_{2}\right)$ at the higher wave number and $v\left(\mathrm{M}_{3}-\mathrm{S}\right)$ at lower wave numbers.

Electrochemical study: Both the molybdenum-tungsten mixed-metal clusters $\left.\mathrm{Cs}_{2}\left[\mathrm{WMo}_{2} \mathrm{~S}_{4}\left(\mathrm{C}_{2} \mathrm{O}_{4}\right)_{3}\right]\left(\mathrm{H}_{2} \mathrm{O}\right)_{3}\right] \cdot 2 \mathrm{H}_{2} \mathrm{O}$ and $\mathrm{Cs}_{2}\left[\mathrm{MoW}_{2} \mathrm{~S}_{4}\left(\mathrm{C}_{2} \mathrm{O}_{4}\right)_{3}\left(\mathrm{H}_{2} \mathrm{O}\right)_{3}\right] \cdot 2 \mathrm{H}_{2} \mathrm{O}$ show the similar three reduction processes as do $\mathrm{Cs}_{2}\left[\mathrm{Mo}_{3} \mathrm{~S}_{4}\left(\mathrm{C}_{2} \mathrm{O}_{4}\right)_{3}\left(\mathrm{H}_{2} \mathrm{O}\right)_{3}\right] \cdot 2 \mathrm{H}_{2} \mathrm{O}$ and $\mathrm{Cs}_{2}\left[\mathrm{~W}_{3} \mathrm{~S}_{4}\left(\mathrm{C}_{2} \mathrm{O}_{4}\right)_{3}\left(\mathrm{H}_{2} \mathrm{O}\right)_{3}\right] \cdot 2 \mathrm{H}_{2} \mathrm{O}$.

The cyclic-voltammogram of $\mathrm{Cs}_{2}\left[\mathrm{WMo}_{2} \mathrm{~S}_{4}\left(\mathrm{C}_{2} \mathrm{O}_{4}\right)_{3}\left(\mathrm{H}_{2} \mathrm{O}\right)_{3}\right]$. $2 \mathrm{H}_{2} \mathrm{O}$ shows two electrochemically quasi-reversible and one chemically reversible redox couples appear at -0.6 and $-1.2 \mathrm{~V}$ respectively, although the third reduction peak disappears because of the very large catalytic $\mathrm{H}_{2}$-evolution. Sharp redox peak at $-0.75 \mathrm{~V}$ due to the strong adsorption of $\left[\mathrm{WMo}_{2} \mathrm{~S}_{4}\left(\mathrm{C}_{2} \mathrm{O}_{4}\right)_{3}\right.$ $\left.\left(\mathrm{H}_{2} \mathrm{O}\right)_{3}\right]^{2-}$ on the electrode overlap the peaks of the first reduction process.

Thus, the electrolysis yields the one-electron reduction product $\left[\mathrm{WMo}_{2} \mathrm{~S}_{4}\left(\mathrm{C}_{2} \mathrm{O}_{4}\right)_{3}\left(\mathrm{H}_{2} \mathrm{O}\right)_{3}\right]^{3-}$ which is stable in the inert atmosphere only but is readily re-oxidized to $\left[\mathrm{WMo}_{2} \mathrm{~S}_{4}\left(\mathrm{C}_{2} \mathrm{O}_{4}\right)_{3}\left(\mathrm{H}_{2} \mathrm{O}\right)_{3}\right]^{2-}$ when exposed to air. The UV-VIS spectra of the solution before and after the bulk electrolysis are shown in Fig. 4a and b. The reversible conversion of the spectra of the clusters was confirmed through several cycles of electrolytic reduction and air-oxidation, indicating the stability of cores. The reduction product which is a mixedmetal and mixed valance cluster, has absorption maxima at 780,610 and $350 \mathrm{~nm}$.

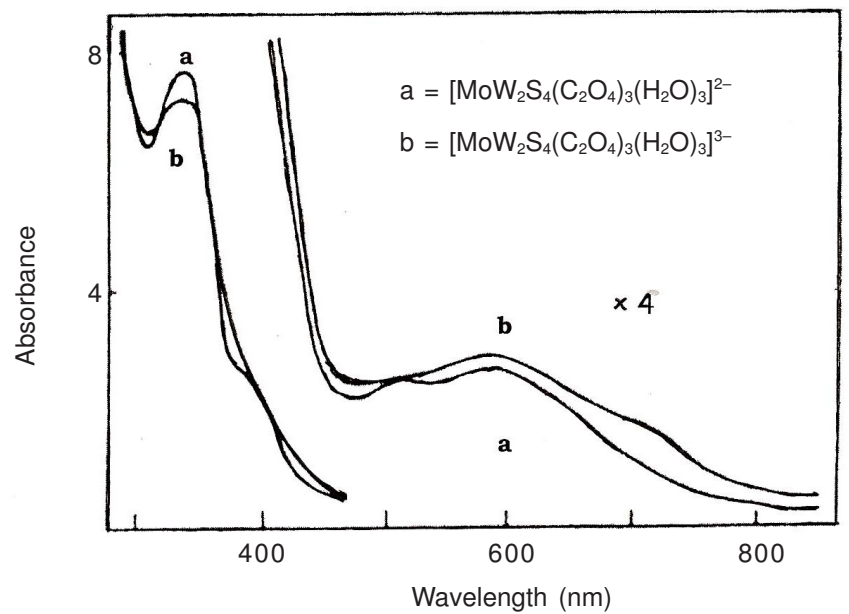

Fig. 4. Electronic spectrum of $\left[\mathrm{MoW}_{2} \mathrm{~S}_{4}\left(\mathrm{C}_{2} \mathrm{O}_{4}\right)_{3}\left(\mathrm{H}_{2} \mathrm{O}\right)_{3}\right]^{2-}$ and $\left[\mathrm{MoW}_{2} \mathrm{~S}_{4}\right.$ $\left.\left(\mathrm{C}_{2} \mathrm{O}_{4}\right)_{3}\left(\mathrm{H}_{2} \mathrm{O}\right)_{3}\right]^{3-}$ in $0.1 \mathrm{MKCl}$

Another molybdenum-tungsten mixed-metal cluster complex $\mathrm{Cs}_{2}\left[\mathrm{Mo}_{2} \mathrm{~W}_{2} \mathrm{~S}_{4}\left(\mathrm{C}_{2} \mathrm{O}_{4}\right)_{3}\left(\mathrm{H}_{2} \mathrm{O}\right)_{3}\right] \cdot 2 \mathrm{H}_{2} \mathrm{O}$ shows three consecutive one electron reduction processes in the cyclic voltammetric measurements. The first reduction process at the mercury electrode, is also overstepped by the absorption redox couple at $0 .>$ V. Fig. 5a and b shows UV-visible spectra of the solution before and after the controlled potential electrolysis at $-1.2 \mathrm{~V}$. The electrolysis is coulometrically confirmed to be a one electron reduction process to give the mixed-metal and mixed-valance cluster $\left[\mathrm{MoW}_{2} \mathrm{~S}_{4}\left(\mathrm{C}_{2} \mathrm{O}_{4}\right)_{3}\left(\mathrm{H}_{2} \mathrm{O}\right)_{3}\right]^{3-}$ that has absorption maxima at $720(\mathrm{sh}), 580,340 \mathrm{~nm}$.

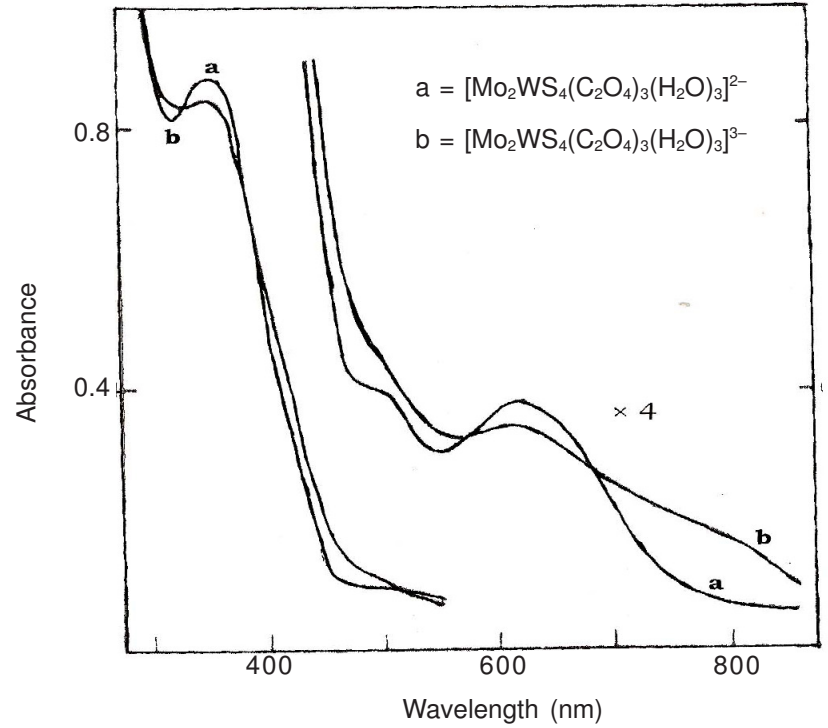

Fig. 5. Electronic spectrum of $\left[\mathrm{Mo}_{2} \mathrm{WS}_{4}\left(\mathrm{C}_{2} \mathrm{O}_{4}\right)_{3}\left(\mathrm{H}_{2} \mathrm{O}\right)_{3}\right]^{2-}$ and $\left[\mathrm{Mo}_{2} \mathrm{WS}_{4}\right.$ $\left.\left(\mathrm{C}_{2} \mathrm{O}_{4}\right)_{3}\left(\mathrm{H}_{2} \mathrm{O}\right)_{3}\right]^{3-}$ in $0.1 \mathrm{MKCl}$

The cyclic voltammogram of $\mathrm{Cs}_{2}\left[\mathrm{MoW}_{2} \mathrm{~S}_{4}\left(\mathrm{C}_{2} \mathrm{O}_{4}\right)_{3}\left(\mathrm{H}_{2} \mathrm{O}\right)_{3}\right]$ and $\mathrm{Cs}_{2}\left[\mathrm{WMo}_{2} \mathrm{~S}_{4}\left(\mathrm{C}_{2} \mathrm{O}_{4}\right)_{3}\left(\mathrm{H}^{2} \mathrm{O}\right)_{3}\right]$ have been shown in Fig. $6 \mathrm{a}$ and $\mathrm{b}$.
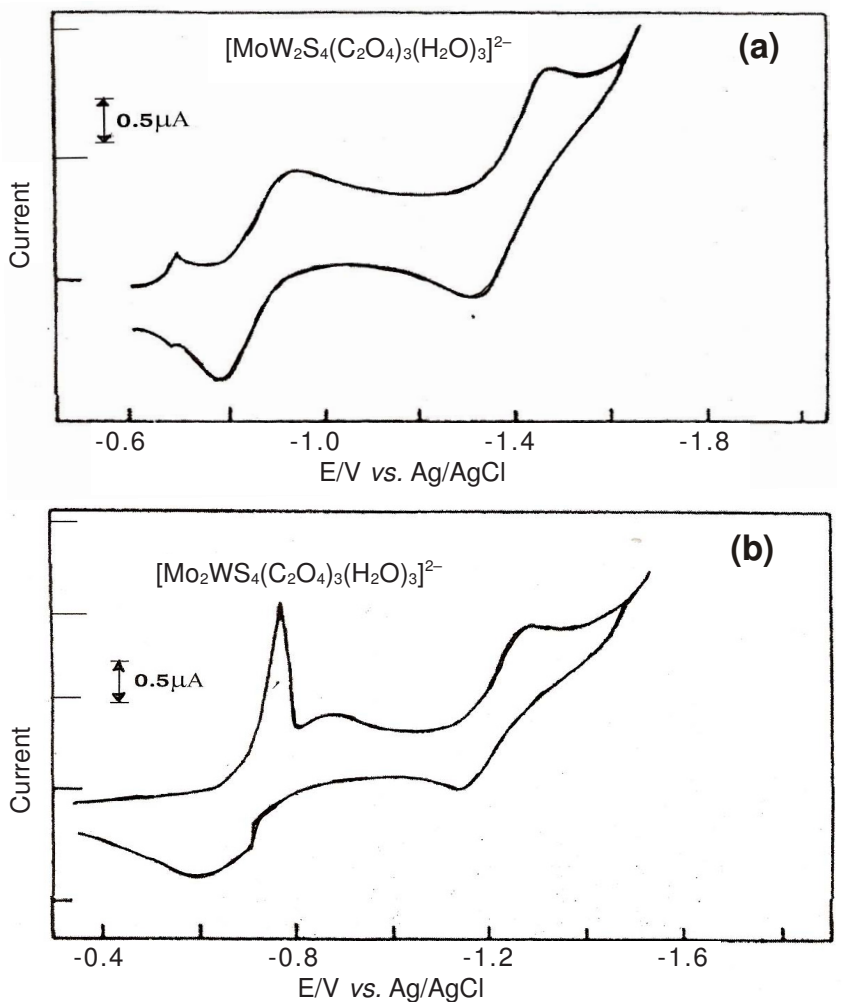

Fig. 6. Cyclic voltammogram of $\left[\mathrm{MoW}_{2} \mathrm{~S}_{4}\left(\mathrm{C}_{2} \mathrm{O}_{4}\right)_{3}\left(\mathrm{H}_{2} \mathrm{O}\right)_{3}\right]^{2-}$ and $\left[\mathrm{Mo}_{2} \mathrm{WS}_{4}\right.$ $\left.\left(\mathrm{C}_{2} \mathrm{O}_{4}\right)_{3}\left(\mathrm{H}_{2} \mathrm{O}\right)_{3}\right]^{3-}$

Table-2 summarizes the half-wave potentials and the wave slopes of the three consecutive one electron reduction preocesses of the molybdenum-tungsten mixed-metal $\mathrm{Cs}_{2}\left[\mathrm{MoW}_{2} \mathrm{~S}_{4}\left(\mathrm{C}_{2} \mathrm{O}_{4}\right)_{3}\left(\mathrm{H}_{2} \mathrm{O}\right)_{3}\right]$ and $\mathrm{Cs}_{2}\left[\mathrm{WMo}_{2} \mathrm{~S}_{4}\left(\mathrm{C}_{2} \mathrm{O}_{4}\right)_{3}\left(\mathrm{H}_{2} \mathrm{O}\right)_{3}\right]$ The potential of the absorption redox couple of the clusters on the mercury electrode is almost independent of the metals 
in the cluster, indicating that the specific treaction with mercury is through the sulfur atom is the clusters with the same order. The catalytic hydrogen evolution wave accompanying the third reduction process depands markedly on the cluster, the catalytic reduction rate is in the order of $\left[\mathrm{W}_{3} \mathrm{~S}_{4}\left(\mathrm{C}_{2} \mathrm{O}_{4}\right)_{3}\left(\mathrm{H}_{2} \mathrm{O}\right)_{3}\right]^{2-}$ $>\left[\mathrm{MoW}_{2} \mathrm{~S}_{4}\left(\mathrm{C}_{2} \mathrm{O}_{4}\right)_{3}\left(\mathrm{H}_{2} \mathrm{O}\right)_{3}\right]^{2-}>\left[\mathrm{WMo}_{2} \mathrm{~S}_{4}\left(\mathrm{C}_{2} \mathrm{O}_{4}\right)_{3}\left(\mathrm{H}_{2} \mathrm{O}\right)_{3}\right]^{2-}>$ $\left[\mathrm{Mo}_{3} \mathrm{~S}_{4}\left(\mathrm{C}_{2} \mathrm{O}_{4}\right)_{3}\left(\mathrm{H}_{2} \mathrm{O}\right)_{3}\right]^{2-}$ while $\mathrm{E}_{1 / 2}$ potentials for IV/III/III $\rightarrow$ III/III/III become less negative in the reverse order.

\begin{tabular}{cccc}
\hline \multicolumn{4}{c}{ TABLE-2 } \\
COMPARISON OF E $\mathrm{F}_{1 / 2}$ FOR THE REDUCTION \\
OF CLUSTERS WITH $\left\{\mathrm{WnMo}_{3-\mathrm{n}} \mathrm{S}_{4}\right\}^{4+}$ CORES \\
\cline { 2 - 4 } Compounds containing & IV, IV, & IV, IV, & IV, III, \\
homo/hetero core & IV/ IV, & III/IV, & III/III, \\
& IV, III & III, III & III, III \\
\hline $\mathrm{Cs}_{2}\left[\mathrm{Mo}_{2} \mathrm{~S}_{4}\left(\mathrm{C}_{2} \mathrm{O}_{4}\right)_{3}\left(\mathrm{H}_{2} \mathrm{O}\right)_{3}\right] \cdot 2 \mathrm{H}_{2} \mathrm{O}$ & $-0.69 \mathrm{~V}$ & $-1.034 \mathrm{~V}$ & -1.39 \\
$\mathrm{Cs}_{2}\left[\mathrm{WMo}_{2} \mathrm{~S}_{4}\left(\mathrm{C}_{2} \mathrm{O}_{4}\right)_{3}\left(\mathrm{H}_{2} \mathrm{O}\right)_{3}\right] \cdot 2 \mathrm{H}_{2} \mathrm{O}$ & $-0.73 \mathrm{~V}$ & $1.08 \mathrm{~V}$ & -1.39 \\
$\mathrm{Cs}_{2}\left[\mathrm{MoW}_{2} \mathrm{~S}_{4}\left(\mathrm{C}_{2} \mathrm{O}_{4}\right)_{3}\left(\mathrm{H}_{2} \mathrm{O}\right)_{3}\right] \cdot 2 \mathrm{H}_{2} \mathrm{O}$ & $-0.84 \mathrm{~V}$ & $-1.40 \mathrm{~V}$ & $-1.78 \mathrm{~V}$ \\
$\mathrm{Cs}_{2}\left[\mathrm{~W}_{3} \mathrm{~S}_{4}\left(\mathrm{C}_{2} \mathrm{O}_{4}\right)_{3}\left(\mathrm{H}_{2} \mathrm{O}\right)_{3}\right] \cdot 2 \mathrm{H}_{2} \mathrm{O}$ & $-1.23 \mathrm{~V}$ & $-1.41 \mathrm{~V}$ & $-1.88 \mathrm{~V}$ \\
\hline
\end{tabular}

The reduction potentials of the mixed-metal clusters lie between those of $\left[\mathrm{Mo}_{3} \mathrm{~S}_{4}\left(\mathrm{C}_{2} \mathrm{O}_{4}\right)_{3}\left(\mathrm{H}_{2} \mathrm{O}\right)_{3}\left(\mathrm{C}_{2} \mathrm{O}_{4}\right)_{3}\right]^{2-}$ and $\left[\mathrm{W}_{3} \mathrm{~S}_{4}\left(\mathrm{C}_{2} \mathrm{O}_{4}\right)_{3}\left(\mathrm{H}_{2} \mathrm{O}\right)_{3}\right]^{2-}$ but are not proportionally distributed for the first reduction process, the potential difference between $\left[\mathrm{MoW}_{2} \mathrm{~S}_{4}\left(\mathrm{C}_{2} \mathrm{O}_{4}\right)_{3}\left(\mathrm{H}_{2} \mathrm{O}\right)_{9}\right]^{2-1 / 3-}$ and $\left[\mathrm{Mo}_{2} \mathrm{~W}_{2} \mathrm{~S}_{4}\left(\mathrm{C}_{2} \mathrm{O}_{4}\right)_{3}\left(\mathrm{H}_{2} \mathrm{O}\right)_{3}\right]^{2-1 / 3-}$ $(90 \mathrm{mV})$ and that between $\left[\mathrm{MoW}_{2} \mathrm{~S}_{4}\left(\mathrm{C}_{2} \mathrm{O}_{4}\right)_{3}\left(\mathrm{H}_{2} \mathrm{O}\right)_{3}\right]^{3-14-}$ and $\left[\mathrm{WMo}_{2} \mathrm{~S}_{4}\left(\mathrm{C}_{2} \mathrm{O}_{4}\right)_{3}\left(\mathrm{H}_{2} \mathrm{O}\right)_{3}\right]^{3-14-}(110 \mathrm{mV})$. The largest potential difference for the second and third processes lies between $\left[\mathrm{Mo}_{2} \mathrm{WS}_{4}\left(\mathrm{C}_{2} \mathrm{O}_{4}\right)_{3}\left(\mathrm{H}_{2} \mathrm{O}\right)_{3}\right]^{3-/ 4-}$ and $\left[\mathrm{MoW}_{2} \mathrm{~S}_{4}\left(\mathrm{C}_{2} \mathrm{O}_{4}\right)_{3}\left(\mathrm{H}_{2} \mathrm{O}\right)_{3}\right]^{3-/ 4-}$ and $\left[\mathrm{MoW}_{2} \mathrm{~S}_{4}\left(\mathrm{C}_{2} \mathrm{O}_{4}\right)_{3}\left(\mathrm{H}_{2} \mathrm{O}\right)_{3}\right]^{4-/ 5-}$ and $\left[\mathrm{W}_{3} \mathrm{~S}_{4}\left(\mathrm{C}_{2} \mathrm{O}_{4}\right)_{3}\left(\mathrm{H}_{2} \mathrm{O}\right)_{3}\right]^{4-/ 5-}$ respectively.

These result suggest that the proceeding reduction centre of the molybdenum-tungsten mixed-metal clusters is mainly on the Mo atoms rather than the $\mathrm{W}$ atoms. Thus the electrode reactions are formally described as:

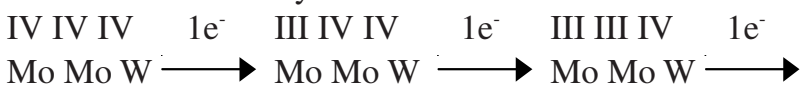

III III III

Mo Mo W for complex containing $\left[\mathrm{Mo}_{2} \mathrm{WS}_{4}\right]^{4+}$ core and

$\begin{array}{ll}\text { IV IV IV } 1 \mathrm{e}^{-} & \text {III IV IV } 1 \mathrm{e}^{-} \\ \mathrm{MoW} \mathrm{W} \longrightarrow & \text { III III IV } 1 \mathrm{e}^{-} \\ \mathrm{MoWW} \longrightarrow\end{array}$

\section{III III}

Mo W W for complex containing $\left[\mathrm{W}_{2} \mathrm{MoS}_{4}\right]^{4+}$ core respectively.
The spectroscopic measurements involving ESR spectroscopy may help to elucidate in more detail about the electronic states of the reduced clusters especially the mixed-metal mixedvalence cluster, but due to the instability of reduced species, the corresponding clusters were not isolated successfully for their further spectroscopic study. However, the experimental work on the synthetic procedure is being under progress for further study. In these oxalato complexes, the molybdenum system, $\mathrm{Cs}_{2}\left[\mathrm{Mo}_{3} \mathrm{~S}_{4}\left(\mathrm{C}_{2} \mathrm{O}_{4}\right)_{3}\left(\mathrm{H}_{2} \mathrm{O}\right)_{3}\right]$, shows as reversible one electrode reduction with $\mathrm{E}_{1 / 2}=-0.689 \mathrm{~V} v s$. $\mathrm{Ag}-\mathrm{AgCl}$ with the appearance of cathodic peak potential at $-0.733 \mathrm{~V}$ along with another ill-defined reduction centered at $-1.034 \mathrm{~V}$. The corresponding tungsten complex shows an irreversible reduction at $-1.23 \mathrm{~V}$. In the oxalato complex, We could not locate any anodic peak for oxidation up to $+0.6 \mathrm{~V}$ because of the limitation of potential window of solvent water.

\section{ACKNOWLEDGEMENTS}

One of the authors, Ramjee Sah, expressed his sincere gratitude to Dr. S. Sarkar, Professor and Head, Chemistry Department, Indian Institute of Technology, Kanpur for his valuable suggestion and proper guidance.

\section{REFERENCES}

1. (a) T. Shibahara, Coord. Chem. Rev., 123, 73 (1993); (b) T. Shibahara, Adv. Inorg. Chem., 37, 143 (1991).

2. (a) T. Shibahara, M. Yamasaki, G. Sakane, K. Minami, T. Yabuki and A. Rhimura, Inorg. Chem., 31, 640 (1992); (b) Q.- T. Liu, J.-X. Lu and A.G. Sykes, Inorg. Chim. Acta, 200, 623 (1992).

3. F.A. Cotton and S.K. Mandal, Inorg. Chim. Acta, 192, 71 (1992).

4. F.A. Cotton and W. Schwotzer, Angew. Chem., 94, 652 (1982).

5. M.H. Chisholer, K. Folting, J.C. Huffman and E.M. Kober, Inorg. Chem., 24, 241 (1985).

6. (a) B. Wang, Y. Sasaki, A. Nagasawa and T. Ito, J. Am. Chem. Soc., 108, 6059 (1986); (b) B. Wang, Y. Sasa ki, S. Ikari, K. Kimura and T. Ito, Chem. Lett., 1955 (1987).

7. A. Patel and D.T. Richers, J. Chem. Soc. Chem. Commun., 274 (1990).

8. H. Brunner, H. Kanermann and J. Wachter, J. Organomet. Chem., 265, 189 (1984).

9. (a) N.Y. Zhu, Y.-F. Zhing and X.-T. Wn, Inorg. Chem., 29, 2705 (1990); (b) N.-Y. Zhu, Y.-F.- Zhing and X.-T. Wu, Polyhedram, 10, 2743 (1991).

10. N.-Y, Zhu, Y.-F. Zheing and X.-T. Wu, J. Chem. Soc. Chem. Common, 235 (1991).

11. (a) T. Shibahara, M.Y. Saki, T. Watase and A. Ichimura, Inorg. Chem., 33, 292 (1994); (b) A. Mullier, V.P. Feddin, E. Dienmann, H. Bogge, E. Krickemeyer, D. Solter, A.M. Guuliani, R. Barbieri and P. Adler, Inorg. Chem., 33, 2243 (1994). 